\title{
Power on Wrist for Women and School Children to Testimony by GPS and GSM using Wireless Personal Area Network
}

\author{
K. Subbulaksmi, R. Hema, S. Ramya
}

\begin{abstract}
In India, many girls are being kidnapped and killed. They don't have proper security within the cities. There's no measure taken until now for increasing the protection or informing where they have been kidnapped. To overcome this problem, we have a tendency to develop a security watch that may detect the location, where she is taken through and send message to their friends or family about the location wherever she is taken to. This will be developed by using embedded system and GPS technology. Our system provides an exact location to the person for whom we need to send about the kidnapping activity done by strangers. This increases the security measures for the women's. This can even be used for children's and other persons who want high security precautions. In 20th century folks expect new technologies like automation in home appliances. So by victimization PIC and GSM we are able to manage the automated home appliances like automatic door locking system and that we can notice gas leakage victimization using gas sensors and alarm intimation.
\end{abstract}

Index terms: GSM-Global System for Mobile Communication

GPS-Global Positioning System; UART-Universal Asynchronous Receiver and Transmitter.

\section{INTRODUCTION}

his Now a day's kidnapping has become very common. Safety for women and school children is decreasing day by day. Till now remedies has not been taken for their safety. The crime rate is increasing and in the same way safety is decreasing. Harassments on women are also increasing by kidnapping them and demanding money from the family members. This problem has become more common mostly in every family. The Indian Government is bringing up new laws but all is in vain. Proper steps are to be taken to overcome this problem of kidnapping. So, for that we have chosen electronic device as the best remedy. We have created a hardware which is to be controlled by software. That is what Embedded System means. This embedded system looks like a normal watch. But it will not show time. As said before it is a remedy for the people's safety [1-5].This watch will contain three micro buttons. One is for safety purpose, other is for light control and the third one is for door locking system. When first button is pressed automatically the GPS inside the watch

Revised Manuscript Received on August 22, 2019.

K. Subbulaksmi, Department of Electronics and Communication Engineering, Bharath Institute of Higher Education and Research, Chennai, Tamilnadu, India.

R. Hema, Department of Electronics and Communication Engineering, Bharath Institute of Higher Education and Research, Chennai, Tamilnadu, India.

S. Ramya, Department of Electronics and Communication Engineering, Bharath Institute of Higher Education and Research, Chennai, Tamilnadu, India.

Retrieval Number: F10820886S219/2019@BEIESP will track the location and through GSM message will be sent to any of the family member whose number is saved during the programming. All this is done with the help of a Microcontroller, GSM and GPS mainly. The other parts like UART, RF Receiver and Transmitter are also used in the process. We have also included some other applications along with this safety unit. The applications are Light ON and OFF system and Automatic Door Locking System mainly for physically challenged people, Gas leakage Detection and alarm intimation using LPG Gas Sensor. When second button is pressed light is being controlled and in the same way if third button is pressed door is locked. The door will open only when the button is pressed one more time and is same case for light also. For controlling these applications we are using relay switch for light control, DC motor for door locking and unlocking, and ADC for gas sensing detection and alarm intimation [6-9].

\section{BLOCK DIAGRAM}

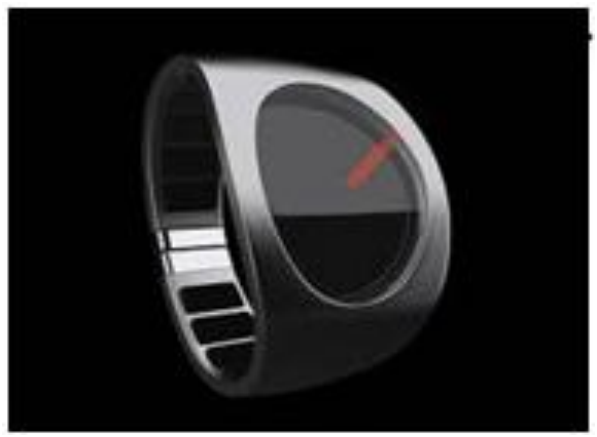

Watch Outlook

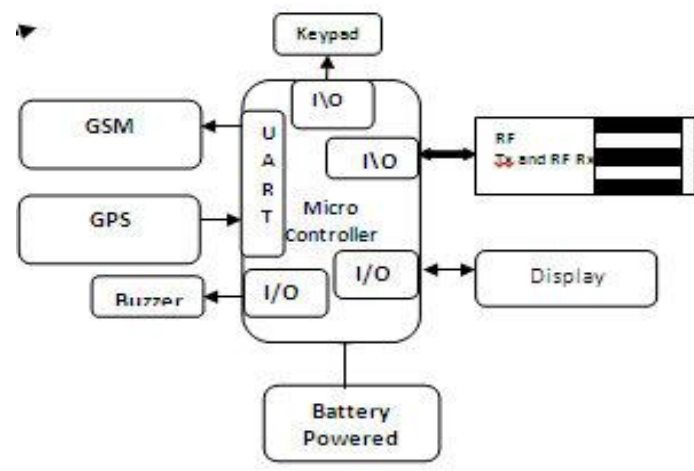

Published By: Blue Eyes Intelligence Engineering \& Sciences Publication 
Hardware Used:

- PIC16f877A

- SIM300 GSM Modem

- GPS Modem

- Safety Key

- 9v Battery

Software Used:

- MPLAB IDE

- C18 Compiler

- Embedded C Programming Language [10-13].

\section{RESULTS AND DISCUSSION}

The women can have the security watch unit with them. Once a intruder kidnaps her, she is going to. The PIC Microcontroller can get the security key as input and locates the location of the place wherever is taken to by the GPS. The Microcontroller can get the latitude and longitude value from GPS modem through UART communication and sends the details to the person's friend or family member through GSM modem by sending a message which contains the details of the location immediately. And nowadays, the expectations of people in their quality of life are growing as the technology is continually on the rise. People needed an smart and sensible scheme that could render their life more convenient and sophisticated, and additional safety is needed. This automation scheme is an electrical and electronic scheme intended with a watch module to control home appliances. The two main technologies used in the system are microchip GSM and PIC. SIM 900 GSM Module is selected in this scheme to receive the order from the GSM receiver and transfer it to the controller. As It has also rendered it feasible to integrate mobile technology into home automation technologies as a consequence of quickly progressing mobile communication technology and broad accessibility. GSM AT command is used for GSM modem and microcontroller interaction. PIC microcontroller, which is PIC16f877A, is the primary device. The SIM900 GSM module is linked in TTL mode via RF Tx \& Rx connector. Using AT commands, each will interact. And we're going to regulate electrical equipment using the relay panel. Using GUI Mobile Application is used the GSM Module for SMS Communication. To generate an audible warning signal, a buzzer is linked. This LPG Gas sensor is used in the home security system to construct wireless Gas Leak Detector [14-20].

\section{CONCLUSION}

Thus a wrist watch for women's and school children's safety using wireless personal area network is successfully implemented using an 8-bit micro controller. The GPS is employed for tracking the locations and GSM is used for sending the SMS ALERT. Similarly for home appliances, relay for light control, DC motor for Door locking and unlocking, ADC and LPG gas sensor for gas leakage detection are being used. The watch is implemented in transmitter unit and for controlling home appliances is done in receiver unit. Thus this device is not only used as a safety kit but is also additionally used for multipurpose like home appliances, gas leak sensing etc.

\section{REFERENCES}

[1] Kongkham, D. \& Sundararajan, M. 2019, "Distributed wideband sensing method for faded dynamic spectrum access", International Journal of Innovative Technology and Exploring Engineering, vol. 8, no. 10 , pp. $4309-4312$

[2] Balaji, S., John Paul Praveen, A. \& Mohanraj, R. 2019, "Recognizable proof and analysis of palm print in biometric authentication system using bayes techniques", International Journal of Innovative Technology and Exploring Engineering, vol. 8, no. 9 Special Issue 3, pp. 1126-1129.

[3] Kavitha, G., Priya, N., Velvizhi, R. \& Allin Geo, A.V. 2019, "Parallel computation in correspondence and signal processing", International Journal of Innovative Technology and Exploring Engineering, vol. 8, no. 9 Special Issue 3, pp. 1136-1139.

[4] Hema, R., Sundararajan, M. \& Balaji, S. 2019, "Smartphone control robot with automatic firing gun", International Journal of Innovative Technology and Exploring Engineering, vol. 8, no. 9 Special Issue 3, pp. 625-627.

[5] Kaliyamurthie, K.P., Sundar Raj, B., Velvizhi, R. \& Shanmugapriya, K. 2019, "Dual band paper substrate CPW antenna for wireless applications", International Journal of Innovative Technology and Exploring Engineering, vol. 8, no. 9 Special Issue 3, pp. 605-608.

[6] Geo, A.V.A., Arunachalam, A.R., Michael, G. \& Elankavi, R. 2019 "Evaluating architecture using compact modalities", International Journal of Innovative Technology and Exploring Engineering, vol. 8, no. 9 Special Issue 3, pp. 836-838.

[7] Theivasigamani, S., Jeyapriya, D. \& Anita Davamani, K. 2019 "Anamoly analyzing and exploring for wireless sensor networks", International Journal of Innovative Technology and Exploring Engineering, vol. 8, no. 9 Special Issue 3, pp. 1116-1118.

[8] Jeyapriya, D., Theivasigamani, S., Velvizhi, R. \& Nandhini, P. 2019, "Program detection in wireless feeler networks", International Journal of Innovative Technology and Exploring Engineering, vol. 8, no. 9 Special Issue 3, pp. 1194-1195.

[9] Gowri Sankaran, B., Karthik, B. \& Vijayaragavan, S.P. 2019, "Image compression utilizing wavelet transform", International Journal of Innovative Technology and Exploring Engineering, vol. 8, no. 10, pp. 4305-4308.

[10] Gowri Sankaran, B., Karthik, B. \& Vijayaragavan, S.P. 2019, "Weight ward change region plummeting change for square based image huffman coding", International Journal of Innovative Technology and Exploring Engineering, vol. 8, no. 10, pp. 4313-4316.

[11] Hema, R., Sundararajan, M. \& Balaji, S. 2019, "Smartphone control robot with automatic firing gun", International Journal of Innovative Technology and Exploring Engineering, vol. 8, no. 9 Special Issue 3, pp. 625-627.

[12] Rangaswamy, K. \& Rajabhushanam, C. 2019, "Congestion control in wireless network using TCP friendly rate control (TFRC)", International Journal of Recent Technology and Engineering, vol. 8, no. 2 Special issue 3, pp. 1598-1602.

[13] Tamil Selvan, S. \& Sundararajan, M. 2019, "Performance Parameters of 3 Value 8t Cntfet Based Sram Cell Design Using H-Spice", International Journal of Recent Technology and Engineering, vol. 8, no. 2 Special issue 5, pp. 22-27.

[14] Vinoth, V.V. \& Kanniga, E. 2019, "Steganographical techniques in hiding text images - system", International Journal of Recent Technology and Engineering, vol. 8, no. 2, pp. 6535-6537.

[15] Saravana, S., Balaji, S., Arulselvi, S. \& John Paul Praveen, A. 2019, "Reliable power quality monitoring and protection system", International Journal of Innovative Technology and Exploring Engineering, vol. 8, no. 9 Special Issue 3, pp. 644-645.

[16] Sundaramoorthy, A. \& John Wiselin, M.C. 2019, "Single patch antenna with multiple feed", International Journal of Innovative Technology and Exploring Engineering, vol. 8, no. 9, pp. 1743-1747.

[17] Velavan, R., Bharanidharan, S. \& Sheeba, B. 2019, "EMF pollution Causes, effects and protection", International Journal of Innovative Technology and Exploring Engineering, vol. 8, no. 9 Special Issue 3, pp. 1166-1168.

[18] Veer, R.A., Arulselvi, S. \& Karthik, B. 2019, "Construction of ensemble square classification approaches in MIMO OFDM", International Journal of Engineering and Advanced Technology, vol. 8 , no. 5, pp. 2039-2041.

[19] Agitha, W. \& Kaliyamurthie, K.P. 2019, "Improved energy efficient in WBAN using MAC with cloud computing", International Journal of Innovative Technology and 
Exploring Engineering, vol. 8, no. 8, pp. 2405-2408.

[20] Kastro, G.G. \& Wiselin, M.C.J. 2019, "Design and analysis of stub loaded resonator", International Journal of Recent Technology and Engineering, vol. 8, no. 1 Special Issue4, pp. 272-283.

\section{AUTHORS PROFILE}

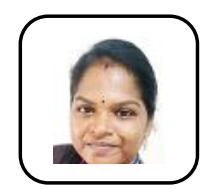

K. Subbulaksmi Assistant Professor, Department of Electronics and Communication Engineering, Bharath Institute of Higher Education and Research, Chennai, India

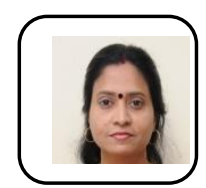

R. Hema Assistant Professor, Department of Electronics and Communication Engineering, Bharath Institute of Higher Education and Research, Chennai, India

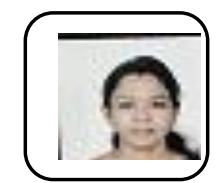

S. Ramya Assistant Professor, Department of Electronics and Communication Engineering, Bharath Institute of Higher Education and Research, Chennai, India 